\title{
Effect of Heat Stress on Conception Rate and Estrus Behavior of Baladi and Crossbred Cows in the Hot Season in Upper Egypt
}

Damarany, A. I.

Department of Animal and Poultry Production, Faculty of Agriculture and Natural Resources, Aswan University, Egypt.

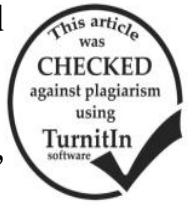

\begin{abstract}
The current work was planned to study the effect of heat stress during the hot season on conception rate and estrus behavior of Baladi and crossbred cows. The cows were observed after month during the post-partum period. The cows divided into two groups, the first group treatment with spraying by water from one day at mating extended to seven days post-mating and the second group as control. The rectal temperature was recorded daily by digital thermometer onset day of mating till seven days post-mating. The present results demonstrated that mean rectal temperature at service and during the next seven days after service were of Baladi and crossbred cows that sprayed by water was lower $\left(38.75 \pm 0.15\right.$ and $\left.38.77 \pm 0.15^{\circ} \mathrm{C}\right)$ than control group $\left(39.18 \pm 0.26\right.$ and $\left.39.54 \pm 0.24{ }^{\circ} \mathrm{C}\right)(P<0.05)$ respectively. The overall conception rate of Baladi cows was higher $42.5 \%$ compared to crossbred cows $35 \%$ during the hot months. Conception rate in Baladi and crossbred cows was higher in cows that sprayed by water $(60$ and $50 \%)$ than control group $(25$ and $20 \%)$ respectively. The occurrence rate $(\%)$ of heat signs (vaginal mucus discharge and mounting behavior) was more frequent in Baladi cows (45 and 50\%) than crossbred cows (40 and 35\%) respectively, but the difference was not significant $(P<0.05)$. Concentrations of progesterone at estrus was higher $(0.323 \pm 0.091$ and $0.301 \pm 0.053 \mathrm{ng} / \mathrm{ml})$ in pregnant than non-pregnant cows $(0.247 \pm 0.042$ and $0.211 \pm 0.031 \mathrm{ng} / \mathrm{ml})$ in two breeds Baladi and crossbred cows $(\mathrm{P}<0.05)$ respectively. The present results clarified that treatment of the cows by spraying by water from the first day at mating till seven days post-mating lead to improve conception rate during the hot season. Therefore, this study recommends spraying water on cows before and after the mating period directly (body cooling) to improve fertility during the hot season under climatic conditions of Aswan Governorate.
\end{abstract}

Keywords: Rectal temperature, hot season, cows, conception rate, water spraying

\section{INTRODUCTION}

Concerning of global warming had been increased since the last 10 years. The global warming will lead to increase the heat stress of the livestock and influence on all physiological process finally negative impact on productive and reproductive performance. Many researches White et al. (2002); Collier et al. (2006) and Ferreira et al. (2011) concerned by study the adverse effect of heat stress in cows on reproductive performance. Conception rate considered one of important reproductive parameters which used in order to measure the reproductive performance of cows. Flamenbaum and Ezra (2006) and Nabenishi et al. (2011) recorded that lower conception rate during the hot season compared with cool season. In India, Khan et al. (2013) found that heat stress was one of the major causes for impaired in a pregnancy rates of crossbred cows. In Brazil, De Souza et al. (2016) found that there is relationship between rectal temperature at insemination and conception rate in crossbred dairy cows. In Egypt, El-Wishy (2013) El-Tarabany and ElBayoumi (2015) reported that lower conception rate of Holstein cows when the cows exposure to high THI. Heat stress effect on embryo development in cows ElSayed et al. (2006); Ferreira et al. (2011) and Pavani et al. (2015) found that during the hot season less quality of oocytes and lowest tendency to undergo embryo developmental phases. Negative effect of high ambient temperature and high temperature humidity index (THI) on heat expression in cow was demonstrated by Peralta et al. (2005) and Roelofs et al. (2010). In Australia similar trend reported by Morton et al (2007) and Jordan (2003) who found that cows exposure to heat stress have impaired duration and intensity of heat and decline embryonic development. Aswan governorate located in the hot area south of Egypt and record highest air ambient temperature reached to above $\left(40^{\circ} \mathrm{C}\right)$ compared with all another governorates in Egypt. In light of the previous facts beside that no investigations about the effect of heat stress during the hot months on conception rate and how use some methods in order to lightening the harm effects on animals. For that the present study was designed.

\section{MATERIALS AND METHODS}

Location of farm and climatic conditions:

The study carried out in farm of animal that located in Nassr El-Nuba, Aswan governorate. The animals reared in semi shaded farm. The weather of Aswan is high ambient temperature and decline of relative humidity especially during the hot season. The table (1) showed the mean of the ambient temperature, relative humidity and temperature humidity index during the hot months (experimental period). Temperature humidity index (THI) was calculated using the formula purposed by Garcia-Ispierto et al. (2007):

$\mathrm{THI}=[0.8 \times \operatorname{Tmax}+(\mathrm{RH} \min (\%) / 100) \times(\operatorname{Tmax}-14.4)+46.4]$

Table 1. Mean of the ambient temperature $\left({ }^{\circ} \mathrm{C}\right)$, relative humidity $(\%)$ and temperature humidity index during the hot season.

\begin{tabular}{|c|c|c|c|c|c|}
\hline \multirow[t]{2}{*}{$\begin{array}{l}\text { Hot } \\
\text { seasons }\end{array}$} & \multicolumn{2}{|c|}{$\begin{array}{c}\text { Average } \\
\text { Ambient } \\
\text { temperature } \\
\left({ }^{\circ} \mathrm{C}\right)\end{array}$} & \multicolumn{2}{|c|}{$\begin{array}{c}\text { Average } \\
\text { Relative } \\
\text { Humidity } \\
\text { (RH \%) }\end{array}$} & \multirow[t]{2}{*}{ THI } \\
\hline & Min & Max & Min & Max & \\
\hline May & 23.1 & 41.2 & 8 & 16 & 81.50 \\
\hline June & 25.3 & 41.3 & 7 & 16 & 81.24 \\
\hline July & 26.2 & 41.3 & 9 & 18 & 81.87 \\
\hline August & 26.0 & 41.0 & 9 & 20 & 81.59 \\
\hline September & 24.2 & 39.4 & 10 & 22 & 80.42 \\
\hline
\end{tabular}


Experimental animals and feeding:

Total number of 80 Baladi and crossbred cows (Baladi $x$ Friesian) ( $n=40$ cows for each) were used in the current investigation. The cows ranged between $2^{\text {nd }}$ and $5^{\text {th }}$ parity. Body weight at mating was (300 - 400 $\mathrm{kg})$ in Baladi cows and (350 - $450 \mathrm{~kg}$ ) for crossbred cows. Animals were live in traditional farms as semishaded yards. Concentrate feed mixture, darawa (green fodder) and hay wheat offered to the cows during the hot season.

Design of the experiment:

Baladi and crossbred cows ( $n=80$ cows) $(n=40$ cows for each breed) were divided into two groups $(\mathrm{n}=$
20 cows for each breed). The first group $(n=20)$ treated with spraying by water (by hose) from the first day of service till seven days after service and the second group as control $(n=20)$ in two breeds Baladi and crossbred cows. Rectal temperature was recorded daily by digital thermometer onset the day of mating until seven days after service at $(2: 00$ to $5: 00$ p.m.) when cows are most likely to be experiencing elevated body temperature Bewley et al. (2008). Table (2) showed the classification of zones based on THI values in cattle with THI model according to Armstrong (1994).

Table 2 .Classification of zones based on THI values in cattle with THI model Armstrong (1994).

\begin{tabular}{lll}
\hline THI & Stress level & Symptoms in cattle \\
\hline$<72$ & None & Optimum productive and reproductive performance \\
$72-78$ & mild & $\begin{array}{l}\text { Dairy cows seek for shade, increase in respiration rate and dilation of blood vessels } \\
\text { Increase in respiration rate and saliva secretion. } \\
\text { Reduction in feed intake and water consumption. }\end{array}$ \\
Moderate & & $\begin{array}{l}\text { Body temperature is increased and reproductive performances are severely affected in cattle } \\
\text { There is rapid increase in respiration and excessive saliva production. The reproductive } \\
\text { performances in animals are significantly decreased }\end{array}$ \\
& Severe & Heat stress is extreme and cows may die \\
\hline 998 & Danger &
\end{tabular}

Detection of heat and pregnancy diagnosis:

Diurnal visual observation of cows was conformed. Vaginal mucus discharge, standing behavior and mounting behavior this is the main sings of heat in cows that depended on during the experiment. Natural mating by bull was used in the experimental cows. According to Arthur (1964) pregnancy was diagnosed applying rectal palpation sixty days (without any heat sings) after mating.

Calculation of conception rate:

Conception rate calculated as the percentage of cows which pregnant throughout 90 days post-partum from the following method:

Conception rate $=$ Number of cows pregnant $/$ Number of cows mating $\times 100$

Blood samples and analysis:

Blood samples $(10 \mathrm{ml})$ were collected in the morning at day of mating and 21 post-mating in heparinized tubes from the jugular vein. Samples were centrifuged at $3000 \mathrm{rpm}$ for 20 minutes for plasma harvesting. Plasma was separated and stored at $-18{ }^{\circ} \mathrm{C}$ until time of progesterone hormone determination using radioimmunoassay technique.

Statistical analysis:

The statistical design was included one factor (effect of treatment with spraying by water on conception rate) the analysis confirmed by SAS (2002). The following model was used:

Where:

$$
\mathbf{Y i j}=\boldsymbol{\mu}+\mathbf{S i}+\mathbf{e i j}
$$

$\mathbf{Y i j}=$ the observation trait

$\boldsymbol{\mu}=$ overall mean

Si = effect of treatment with spraying by water (non-spraying

$=1$ and spraying $=2$ )

eij= experimental error

Duncan's Multiple Range test (Duncan, 1955) was used to test the significance of difference between means. Chi Squire was performed.

\section{RESULTS AND DISSCUSSION}

\section{Effect of heat stress on conception rate of Baladi and crossbred cows}

The overall conception rate of Baladi cows is presented in table (3). Lower conception rate was recorded in Baladi cows during the experimental period $42.5 \%$. Higher conception rate was observed in the cows that sprayed by water before and during the next seven days after service. There was a positive effect of spraying of water on conception rate of cows $(60 \mathrm{vs}$. $25 \%$, control) table (3). Spraying of water lead to decline the body temperature (rectal temperature) in cows and maintenance in normal range during the hot season may be good reflection on physiological process, feed intake and energy balance. Jahn et al. (2002) reported that increase air ambient temperatures were positive relationship with rectal temperature in dairy cows that exposed to direct solar radiation. The present results are agreement with that reported by Barkawi et al. (2001) and Barkawi et al. (2006) who found that conception rate was lower during the hot season (66.7, $65.1 \%)$ compared with $(87.5,69.9 \%)$ in the cold season in Baladi cows respectively. Similar trend was observed by Zahed et al. (2001) who found that conception rate of Baladi cattle in the cold season was higher $(65.5 \%)$ than in the hot season $(63.8 \%)$.

Lower conception rate was observed in crossbred cows compared with Baladi cows table (3). There is a positive impact of spraying by water on conception rate of crossbred cows (50 vs. 20\%, control) table (3). Spraying the crossbred cows by water contributed to decreasing the body temperature (rectal temperature) and sustainability around the normal limits. The current result agree with that reported by De Souza et al. 
(2016) who found that cows that served in the early morning had lower rectal temperature $\left(38.96^{\circ} \mathrm{C}\right)$ and conception rate was $(32.86 \%)$ compared with that cows mated in the afternoon rectal temperature was $\left(39.60^{\circ} \mathrm{C}\right)$ and conception rate was $26 \%$. Also, the results are agreement with that recorded by Folman et al. (1979) and Ron et al. (1984) who found that conception rate was lower during the hot season $(22,24$ $\%)$ compared with the cool season $(80,52 \%)$ respectively. Similar trend was reported by Ono et al. (2016) who found that pregnancy rates were lower in summer $17.1 \%$ than in winter $40.9 \%$ in cows. Demétrio et al. (2007) and Beltran and Vasconcelos (2008) reported that there was a relation between decline in pregnancy rate and rectal temperature in cows. Khalil et al. (2010) reported that crossbred cows are less heat tolerant compared to Baladi cows under heat stress in Egypt conditions. Al-Katanani et al. (1999) found that increase the ambient temperature 10 days before estrus are associated with low fertility and increment pregnancy loss in dairy cattle. Similar findings were reported by Garcia-Ispierto et al. (2006) who found that about $10 \%$ of pregnancies during early pregnancy were loss in cows.

Most of researchers demonstrated that positive association between increment of air temperature and elevation of body temperature of cows (rectal and vaginal temperature) Sartori et al. (2002); West (2003) and Kendall et al. ( 2007). Thatcher et al. (2010) reported that the main causes of heat stress in dairy cows are increase environmental temperature, solar radiation, and relative humidity. The present results demonstrated lower conception rate during the hot months in two breeds Baladi and their cross cows that reared in Aswan governorate in Upper Egypt (42.5 and $35 \%)$ respectively. The obtained results were agrees with that reported by Nabenishi et al. (2011) who found that conception rate of dairy cows during the warm months (July to September) was lower $29.5 \%$ compared to $38.2 \%$ during the cold months (October to June). Similar trend was reported by Flamenbaum and Ezra (2006) who observed that conception rates of high and low producing cows were lower during the summer season $(19,25 \%)$ as compared to $(39,40 \%)$ in winter season respectively. Higher pregnancy rates in Holstein cows were observed during the cool months (September to November) $32 \%$ but lowest value recorded in the hot months 24\% Oseni et al. (2004). Wide variation in pregnancy rates in cows was showed in hot and cold season (27.7 vs. 68.5\%) respectively Ahmadi and Ghaisari (2007). Recently, Khan et al. (2013) reported that pregnancy rates in dairy cows reared in temperature neutral zone were higher by about $12 \%$ than cows reared in heat stress zone. Cavestany et al. (1985) and De Rensis et al. (2002) found that the percentage of decline in conception rates in cows during the warm months ranged between 20 and $30 \%$ comparison to the cool months.

During the experimental period that extended during the hot months (May to September) the THI (temperature humidity index) was ranged between (80.4 and 81.8) table (1). According Armstrong (1994) the cows suffer from heat stress, the main important symptoms of heat stress on cows are: increase in respiration rate and saliva secretion, reduction in feed intake and water consumption and body temperature is increased and reproductive performances are severely affected in cattle. The current results agreement with that reported by El-Wishy (2013) who found that sharp less in conception rate of cows during the interval from May to July under the climatic conditions of Egypt when the THI (temperature humidity index) increased from 69 to 74. Similar findings observed by ElTarabany and El-Bayoumi (2015) reported that the conception rate of Holstein cows decline from $35.8 \%$ to $16.1 \%$ when the THI increased from ( 70 to 80 ) in Egypt. Garcia-Ispierto et al. (2007) found that when the THI more than 80 on three days before service the conception rate was decline from $30.6 \%$ to $23 \%$ in Holstein cows in North-Eastern Spain. Similar trend was observed by Amundson et al. (2006) who found decline in conception rate when the THI higher than 73 in Nebraska, USA. Pavani et al. (2015) reported that in cows when the THI during the hot season (June to September) was 71.7 the conception rate was $40.2 \%$ but conception rate was higher $63.8 \%$, when the THI 62.8 during the cool season. Higher embryos development showed during the cold season 53.8\% compared to hot season 36.3\%. Morton et al. (2007) and Schuller et al. (2014) reported that the conception rates in dairy cows decreased when the THI increased more than $72-73$.

Calculated of normal body temperature of the cow is about $\left(38.5-38.6^{\circ} \mathrm{C}\right)\left(101.3-101.5^{\circ} \mathrm{F}\right)$ Sartori et al. (2002). There is positive association between environmental temperature and rectal temperature in non-lactating heifers and lactating cows in Wisconsin. Mean rectal temperature at and during the next seven days after service was $38.75^{\circ} \mathrm{C}$ in cows sprayed by water compared to $39.18^{\circ} \mathrm{C}$ in control cows. Hansen (2008) reported that conception rate decreased when rectal temperatures increased above $>102.2^{\circ} \mathrm{F}$ $\left(39.0^{\circ} \mathrm{C}\right)$ as afternoon. Gwazdauskas et al. (1973) found that $12.8 \%$ decrease in conception rate when uterine temperature elevated $0.5^{\circ} \mathrm{C}$ more than normal range in cows. Continuance spraying of the water on the cows during the next seven days after service was responsible for decline the rectal temperature in cows. Synchronized lower rectal temperature in cows sprayed by water with higher conception rate compared to control cows table (3). The present results were correspond with that reported by Vasconcelos et al. (2006) who found that rectal temperature was negatively correlated with the probability of cows becoming pregnant after artificial insemination and embryo transfer. Similar findings were reported by Morton et al. (2007) who found that heat stress 3-5 weeks pre service and one week post service was conjugated with reduction in conception rate in cows. Thatcher et al. (2010) found decline in the pregnancy rate, because the oocyte and sperm is more sensitive at the time of insemination and the early developing embryo to increase of body temperature for 
a short period of time. When uterine temperature at the day post insemination is higher $0.5^{\circ} \mathrm{C}\left(0.9^{\circ} \mathrm{F}\right)$ than 38.3 ${ }^{\circ} \mathrm{C}\left(100.9^{\circ} \mathrm{F}\right)$, the conception rate is lowered by about $7 \%$. For this $38.8^{\circ} \mathrm{C}\left(101.8^{\circ} \mathrm{F}\right)$ uterine temperature was may be conjugated with decline in conception rate of cows. Schuller et al. (2014) reported that lower conception rate around 1 to 21 day pre- mating when the dairy cows exposed to heat stress.

Decline of conception rate during the hot season in two breeds that presented in table (3) may be due to during the hot season nuclear maturation of oocytes is stopped in early phases of meiotic maturation Maya Soriano et al. (2013). Similar observed was reported by El-Sayed et al. (2006) and Ferreira et al. (2011)showed that oocytes during the hot seasons had lowest tendency to undergo embryo developmental phases, also deterioration of oocytes quality while the hot months, trigger to meiotic stop of oocytes at anaphase and telophase. Pavani et al. (2015) reported that cows exposed to heat stress during the hot season affect on physiological responses of dam on follicular and oocyte quality to cause decrease in embryo development. Biggers et al. (1987) reported that heat stress lead to reduction in embryo growth up to day 17 which is a serious time for production of interferon-tau from the embryos. Suitable amounts of interferon-tau are important to reduction pulsatile secretion of prostaglandin F2 $\alpha$ to stop corpus luteum regression and persistency of pregnancy. Similar findings were reported by Putney et al. (1988) who found that heat stress decline protein synthesis and secretion of interferon-tau by $71 \%$ in embryos. Also, endometrial secretion of PG F2 $\alpha$ and embryo secretion of PG E2 is higher in heat stress by $72 \%$. Rocha et al. (1998); AlKatanani et al. (2002) and Ferreira et al. (2011) reported that oocytes incubated during the hot seasons showed decline tendency to development to blastocyst phase after in vitro fertilization compared to oocytes incubated during winter. In addition Ealy et al. (1993) reported that heat stress on day one post- breeding decline development of embryo.

Showed from the present results higher conception rate of Baladi cows compared to crossbred under the hot season conditions and response to treatment with water was better in Baladi cows table (3). The present results may be reflecting that Baladi cows were more adapted to the environmental conditions in Upper Egypt than crossbred cows. The results agreement with that reported by Hansen (2007) who found that Bos-indicus embryos are low adversely affected by increased temperature in culture than Holstein embryos (Bos- taurus). Embryos that produced by insemination of Holstein breeds oocytes with Angus breeds semen less thermotolerant than embryos produced by insemination of Brahman oocytes with Angus semen. Pszczola et al. (2009) demonstrated that decline heat tolerance may be one of the causes for the impaired reproductive performance of dairy cows. Amundson et al. (2006) found that negative correlation between THI and pregnancy rate of Bos taurus crossbred cows.

There was improvement in conception rate in cows that sprayed by water during the next seven days after service in two breeds compared with control group table (3). Showed decline in rectal temperature of cows that sprayed by water during the next seven days after service compared with control group table (3). Berman and Wolfenson (1992) found that improvement in conception rates in cows when used the cooling system with sprinkling during the heat stress period.

Table 3. Mean $\pm \mathrm{SE}$ of rectal temperature at and during seven next days after service and conception rate of Baladi and crossbred cows.

\begin{tabular}{lccccc}
\hline Treatment & Breed & $\begin{array}{c}\text { Rectal temperature at } \\
\text { service }\end{array}$ & $\begin{array}{c}\text { Rectal temperature } \\
\text { during the next seven } \\
\text { days after service }\end{array}$ & $\begin{array}{c}\text { Rectal temperature at } \\
\text { service and during the } \\
\text { next seven days after } \\
\text { service }\end{array}$ & $\begin{array}{c}\text { Conception } \\
\text { Rate (\%) }\end{array}$ \\
\hline $\begin{array}{l}\text { Cows sprayed by water } \\
\text { Control }\end{array}$ & & $39.12 \pm 0.26$ & $38.69 \pm 0.15$ & $38.75 \pm 0.15^{\mathrm{a}}$ & $60^{\mathrm{a}}$ \\
$\begin{array}{l}\text { Overall mean } \\
\text { Cows sprayed by water }\end{array}$ & Baladi & $39.43 \pm 0.13$ & $38.83 \pm 0.24$ & $39.18 \pm 0.26^{\mathrm{b}}$ & $25^{\mathrm{b}}$ \\
$\begin{array}{l}\text { Control } \\
\text { Overall mean }\end{array}$ & & $39.26 \pm 0.19$ & $38.73 \pm 0.14$ & $38.77 \pm 0.13^{\mathrm{a}}$ & 42.5 \\
\hline
\end{tabular}

$\overline{\mathrm{a}, \mathrm{b}}$ : values within the same column having different superscripts are different at $(P<0.05)$.

Estrus behavior of Baladi and crossbred cows during the hot season

The occurrence rate (\%) of estrus symptoms during the hot months in two breeds were lower frequency figure (1). Vaginal mucus discharge and mounting behavior there were more frequent in Baladi cows than crossbred cows table (4). The current results correspond with that reported by Peralta et al. ( 2005) and Roelofs et al. (2010) who found that negative effect of high ambient temperature and high temperature humidity index (THI) on heat expression in cows. Similar findings were reported by Badinga et al. (1993) showed that heat stress destroyed ovarian follicles and causes a decline synthesis of estradiol. This decline in estradiol synthesis leads to impaired expression of estrus, ovulation, and the corpus luteum development. Lower estradiol concentrations cause to decline estrus duration and intensity, and increment incidence of anestrous Wolfenson et al. (1988). Heat stress decrease oestradiol levels at pro-oestrus (Gwazdauskas et al., 1981) and manifestation of heat behavior (Abilay et al., 1975) and this decline percentage of cows are detected in heat (Thatcher and Collier, 1986). Nebel et al. (1997) reported that dairy cows in the hot season had about one-half the number of mounts per estrus corresponds with cows in the winter season. White et al. (2002) 
found that heat expression/detection rate was lesser in hot months when the air ambient temperature was around at $27.6^{\circ} \mathrm{C}$ than that in cool months when the air ambient temperature was $5.8{ }^{\circ} \mathrm{C}$. Low feed intake appears during heat stress cause to negative energy balance in cows lead to decrease LH secretion and increased anovulation cases. De la sota et al. (1998) and Dobson and Smith (2000) reported that low oestradiol secretion from the dominant follicles lead to indigent expression of heat with reduce of heat detection rate. Thatcher and Collier (1986) found that the intensity of heat expression is increment when heat stressed cows are cooled. Morton et al (2007) and Jordan (2003) in Australia, demonstrated that the cows exposure to heat stress have reduced duration and intensity of heat, altered follicular development, and decline embryonic development. Hansen and Arechiga (1999) and De Rensis and Scaramuzzi (2003) reported that motor activity and other symptoms of heat are decreased and the incidence of anoestrus and quiet ovulation are increased by heat stress in hot season. The intensity of heat was more frequent in Baladi cows than crossbred cows figure (1). Regardless of sparing by water the present results may be due to the different of breeds and appears adaptation of Baladi cows to the climatic conditions in Upper Egypt than crossbred cows. The current results agrees with that reported by Pszczola et al. (2009) who found that decrease heat tolerance may be one of the causes for the impaired reproductive performance of cows. Amundson et al. (2006) reported a negative relation between THI and pregnancy rate of crossbred cows.

Table 4. Occurrence rate (\%) of estrus symptoms during the hot months of Baladi and crossbred cows.

\begin{tabular}{lcc}
\hline \multirow{2}{*}{ Estrus symptoms } & \multicolumn{2}{c}{ Breed } \\
& Baladi & Crossbred \\
\hline No. of cases & 20 & 20 \\
Vaginal mucus discharge & $(9 / 20) 45$ & $(8 / 20) 40$ \\
Mounting behavior & $(10 / 20) 50$ & $(7 / 20) 35$ \\
Standing behavior & $(20 / 20) 100$ & $(20 / 20) 100$ \\
\hline
\end{tabular}

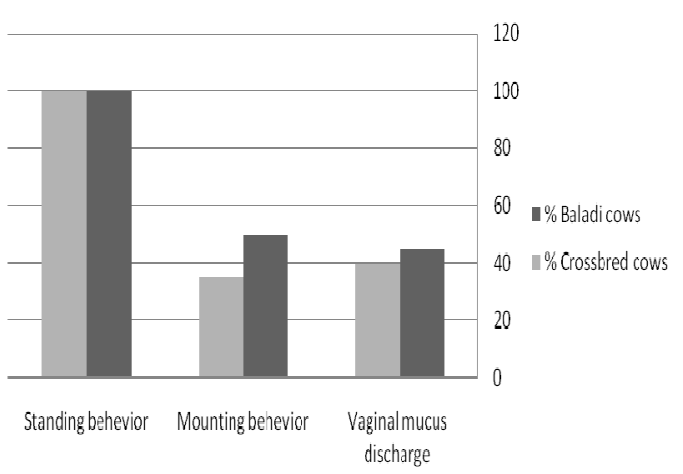

Figure 1.0 ccurrence rate $[\%)$ of estru symptoms during the hot season of Baladi and crossbred cows

Concentrations (ng/ml) of progesterone at estrus and 21 day post-mating of Baladi and crossbred cows
Showed higher concentrations of progesterone at estrus in pregnant cows than non-pregnant in the two breeds Baladi and crossbred cows $(\mathrm{P}<0.05)$ table $(5)$. The present result was agreement with that reported by Waldman et al. (2001) in Norway who found that a strong inverse associated between the probability of non- return and the concentration of progesterone at the time of artificial insemination in cows. Similar finding reported by Busch et al. (2008) observed that pregnant cows had higher progesterone concentration onset on $\mathrm{d}$ 10 post- insemination compared to non pregnant cow. Concentrations of progesterone on 21 day post-mating was higher in Baladi cows than crossbred figure (2), this may be explain why conception rate was higher in Baladi than crossbred cows. The current result agrees with that reported by Lemley et al. (2010) showed that increase progesterone was associated with elevated pregnancy retention and progress in embryonic development. Also, Rivera et al. (2011) found that less embryo quality of cows due to impaired progesterone levels during follicle growth. Cerri et al. (2011) demonstrated that higher concentration of progesterone pre and post- insemination are associated with improved fertility. Progesterone alters ovarian and uterine function by direct or indirect effect fertilization and early stages of embryo development. Alnimer et al. (2002) observed that progesterone concentrations in luteal phase of heat in cold season are higher than in hot season. In addition, Torres-Junior et al. (2008) reported that progesterone concentrations in blood were modified according to changes of environmental temperatures, heat stress fluctuated progesterone metabolism, this affect on follicles and development of corpus luteum. West (2003) showed that progesterone concentrations were altered when the cows exposure to heat stress conditions may be due to the blood flow might fluctuate to peripheral tissues for cooling purposes and consequently decline hepatic catabolism of progesterone. Hahn et al. (2003) found that the decrease in conception rate in hot season is due to the combined effects of environmental heat, which produces a modification in the synthesis of sexual hormones.

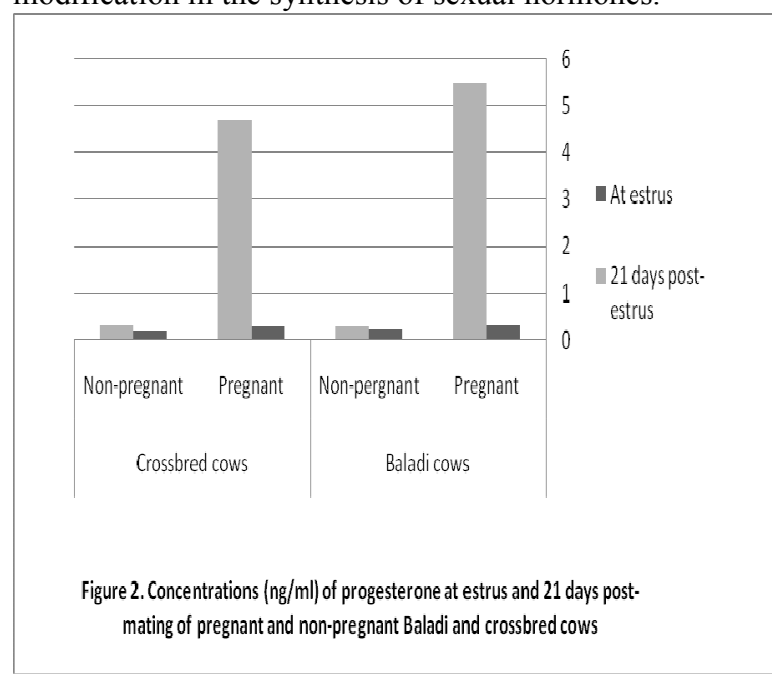


Table 5 . Concentrations $(\mathrm{ng} / \mathrm{ml})$ of progesterone at estrus and 21 day post-mating of Baladi and crossbred cows.

\begin{tabular}{|c|c|c|c|c|}
\hline \multirow{2}{*}{ Time } & \multicolumn{2}{|c|}{ Baladi cows } & \multicolumn{2}{|c|}{ crossbred cows } \\
\hline & Pregnant & Non-pregnant & Pregnant & Non-pregnant \\
\hline At estrus & $0.323 \pm 0.091^{\mathrm{a}}$ & $0.247 \pm 0.042^{b}$ & $0.301 \pm 0.053^{\mathrm{a}}$ & $0.211 \pm 0.031^{\mathrm{b}}$ \\
\hline 21 day post-mating & $5.512 \pm 0.122^{\mathrm{a}}$ & $0.301 \pm 0.012$ & $4.722 \pm 0.211^{\mathrm{b}}$ & $0.311 \pm 0.022$ \\
\hline
\end{tabular}

${ }^{\text {a, b }}$ : values within the same row having different superscripts are different at $(P<0.05)$.

\section{CONCLUSION}

The present results demonstrated that treatment of the cows by spraying by water from the first day at mating till seven days post-mating lead to improve conception rate during the hot season. Therefore, this study recommends spraying water on cows before and after the mating period directly (body cooling) to improve fertility during the hot season under climatic conditions of Aswan Governorate.

\section{REFERENCES}

Abilay, T. A.; H. D. Johnson and M. Madan (1975). Influence of environmental heat on peripheral plasma progesterone and cortisol during the bovine estrous cycle. J. Dairy Sci., 58: 18361840.

Ahmadi, M. R. and H. R. Ghaisari (2007). Heat stress and different timed-AI methods influence on pregnancy rates of dairy cows. Veterinarski Archive, 77 (4): 327-335.

Al-Katanani, Y. M; F. F. Paula-Lopez and P. J. Hansen (2002) Effect of season and exposure to heat stress on oocyte competence in Holstein cows. J Dairy Sci., 85, 390-6.

Al-Katanani, Y. M.; D.W. Webb and P.J. Hansen (1999). Factors affecting seasonal variation in 90-day nonreturn rate to first service in lactating Holstein cows in a hot climate. J. Dairy Sci., 82, 2611-2616.

Alnimer, M.; G. De Rosa; F. Grasso; F. Napolitano and A. Bardi (2002). Effect of climate on the response to three oestrous synchronisation techniques in lactating dairy cows. Anim Reprod Sci., 71, 157-68.

Amundson, J. L.; T. L. Mader; R. J. Rasby and Q.S Hu (2006). Environmental effects on pregnancy rate in beef cattle. J Anim Sci., 84: 3415-3420.

Armstrong, D.V. (1994) Heat stress interactions with shade and cooling. J. Dairy Sci., 77: 2044-2050.

Arthur, G. H. (1964). Method of rectal examination; Wright's Vet. Obs., 1964; 4: 71-80.

Badinga, L.; W.W. Thatcher; T. Diaz; M. Drost and D. Wolfeson (1993) Effect of environmental heat stress on follicular development and steroidogenesis in lactating Holstein cows. Theriogenology, 39: 797-810.

Barkawi, A. H.; G. Ashour; Z. B. Rabie and A. I. Damarany (2006). Reproductive aspects of Egyptian Baladi cattle. Proc. Fourth Conf. Fac. Vet. Med.,Cairo, Egypt, 29-30 July pp: 41-52.

Barkawi, A. H.; G. Ashour; Z. B. Rabie and A. I. Damarany (2001). Post-partum reproductive performance of suckling Egyptian native (Baladi) cattle.Egyptian J. Anim. Prod.,38:79-86.

Beltran, M. P. and J. L. M. Vasconcelos (2008). Conception rate in Holstein cows treated with GnRH or hCG on the fifth day post artificial insemination during summer. Arq. Bras. Med. Vet. Zootec., 60 (3 ): 580-586.
Berman, A. and D. Wolfeson (1992). Environmental modifications to improve production and fertility. In: Large Dairy Herd Management. H.H. Van Horn and C.J. Wilcox., Eds., American Dairy Science Association, Champaign, IL. pp 126-134.

Bewley, J. M.; M. E. Einstein; M. W. Grott and M. M. Shutz (2008). Comparison of reticular and rectal core body temperatures in lactating dairy cows. J. Dairy Sci., 91: $4661-4672$.

Biggers, B. G.; R. D. Geisert; R. P. Wetteman and D. S. Buchanan (1987). Effect of heat stress on early embryonic development in the beef cow. J. Anim. Sci., 64, 1512-1518.

Busch, D. C; J. A. Atkins; J. F. Bader; D. J. Schafer; D. J. Patterson; T. W. Geary and M. F. Smith (2008). Effect of ovulatory follicle size and expression of estrus on progesterone secretion in beef cows J Anim Sci., 86: 553-563.

Cavestany, D., A. B. El-Whish y, R. H. Foot (1985). Effect of season and high environmental temperature on fertility of Holstein cattle. J. Dairy Sci., 68, 1471-1478

Cerri, R. L. A. ; R. C. Chebel; F. Rivera; C. D. Narciso; R. A. Oliveira; W.W. Thatcher and J. E. P. Santos (2011). Concentration of progesterone during the development of the ovulatory follicle: I. Ovarian and embryonic responses. Journal of Dairy Sci., 94: 3342-3351.

Collier, R. J.; G. E. Dahl and M. J. Van-Baale (2006). Major advances associated with environmental effects on dairy cattle. J. Dairy Sci., 89:12441253.

De La Sota, R. L. ; J. M. Burke; C. A. Risco; F. Moreira; M. A. Delorenzo and W. W. Thatcher (1998). Evaluation of timed insemination during summer heat stres in lactating dairy cattle. Theriogenology, 49: 761-770.

Demetrio, D. G. B.; R. M. Santos; C. G. B. Demetrio and J. L. M. Vasconcelos (2007). Factors affecting conception rates following artificial insemination or embryo transfer in lactating Holstein cows. Journal of Dairy Science, Champaign, 90 (11): 5073-5082.

De Rensis , F.; P. Marconi; T. Capelli; F. Gatti ; F. Facciolongo; S. Franzini and R. J. Scaramuzzi (2002). Fertility in postpartum dairy cows in winter or summer following estrous synchronization and fixed time A.I. after the induction of an LH surge with Gonadotropin releasing hormone $(\mathrm{GnRH})$ or human chorionic gonadotropin (hCG). Theriogenology, 58:16751687.

De Rensis, F. and R. J. Scaramuzzi (2003). Heat stress and seasonal effects on reproduction in the dairy cow - a review. Theriogenology, 60: 1139-1151.

De Souza; F. R.; C. C. Campos; N. A. M. Da Silva and R. M. Dos Santos (2016). Influence of seasonality, timing of insemination and rectal temperature on conception rate of crossbred dairy cows. Ciências Agrárias, Londrina, (37): 155-162. 
Dobson, H. and R. F. Smith (2000). What is stress, and how does it affect reproduction. Anim Reprod Sci., 60-61: 743-752.

Duncan, D. B. (1955). Multiple ranges and multiple F. Test. Biometrics, 11:1-24.

Ealy, A. D.; M. Drost and P.J. Hansen (1993). Developmental changes in embryonic resistance to adverse effects of maternal heat stress in cows. J. Dairy Sci., 76: 2899-2905.

El-Sayed, A. M.; F. Hoelker; D. Rings; D. Slilew; E. Jennen; M. A. Tholen; K. Sirard and D. Schellander Tesfaye (2006). Large-scale transcriptional analysis of bovine embryos biopsies in relation to pregnancy success after transfer to recipients. Physiol. Genomics, 28:8496.

El-Tarabany, M.S. and K. M. El-Bayoumi (2015). Reproductive performance of backcross Holstein $\mathrm{x}$ Brown Swiss and their Holstein contemporaries under subtropical environmental conditions. Theriogenology, 83: 444-448.

El-Wishy, A. B. (2013). Fertility of Holstein cattle in a subtropical climate of Egypt. Iran. J. Appl. Anim. Sci., 3(1): 45-51.

Ferreira, R. M.; H. Ayres; M. R. Chiaratti; M. L. Ferraz; A. B. Araújo; C. A. Rodrigues; Y. F. Watanabe; A. A. Vireque; D. C. Joaquim; L. C. Smith; F. V. Meirelles and P. S. Baruselli (2011). The low fertility of repeat-breeder cows during summer heat stress is related to a low oocyte competence to develop into blastocysts. J. Dairy Sci., 94:2383-2392.

Flamenbaum, I. and E. Ezra (2006). Cooling cows in summer almost eliminates seasonality in milk production and fertility. In: The Dairy Industry in Israel. D Hojman, Y Malul, and T Avrech (ed), Israel Cattle Breeders Assn and Israel Dairy Board, Israel, pp 23-25.

Folman, Y.; A. Berman; Z. Herz; M. Kaim; M. Rosenberg and S. Gardin (1979). Milk yield and fertility of high-yielding dairy cows in a subtropical climate during summer and winter. J. Dairy Res., 46:411.

Garcia Ispierto, I.; F. Lopez-Gatius; G. Bech-Sabat; P. Santolaria; J. L. Yaniz; C. Nogareda; F. De Rensis and M. Lopez-Bejar (2007). Climate factors affecting conception rate of high producing dairy cows in northeastern spain. Theriogenology, 67:1379-1385.

Garcia-Ispierto, I.; F. Lopez-Gatius; P. Santolaria; J. L. Yaniz; C. Nogareda; M. Lopez-Béjar and F. De Rensis (2006). Relationship between heat stress during the peri-implantation period and early fetal loss in dairy cattle. Theriogenology, 65:799807.

Gwazdauskas, F. C.; W. W. Thatcher; C. A. Kiddy; M. J. Pape and C. J. Wilcox (1981). Hormonal pattern during heat stress following PGF2 alphatham salt induced luteal regression in heifers. Theriogenology, 16: 271-285.

Gwazdauskas, F. C.; W. W. Thatcher and C. J. Wilcox (1973). Physiological, environmental, and hormonal factors at insemination which may affect conception. J Dairy Sci., 56:873-877.

Hahn, G. L.; T. L. Mader and R. A. Eigenberg (2003). Perspectives on development of thermal indices for animal studies and management. In: Proceeding Symposium. Interactions between Climate and Animal Production EAAP Technical Series , 7:31-44.
Hansen, P. J. and C. F. Aréchiga (1999). Strategies for managing reproduction in the heat-stressed dairy cow. J Anim Sci., 82 Suppl (2): 36-50.

Hansen, P.J. (2007). Exploitation of genetic and physiological determinants of embryonic resistance to elevated temperature to improve embryonic survival in dairy cattle during heat stress. Theriogenology, 68S:S242-S249.

Jahn, E.; S. Arredondo; W Bonilla, and A. Del Pozo (2002). Efecto de la temperature y la suplementacion energetica sobre la produccion de leche en vacas lecheras a pastoreo. Agricultura Tecnica, 62: 245-254.

Jordan, E. R. (2003). Effects of heat stress on reproduction. J Dairy Sci., 86: 104-114.

Kendall, P. E.; G. A. Verkerk; J. R. Webster and C. B. Tucker (2007). Sprinklers and shade cool cows and reduce insect-avoidance behavior in pasturebased dairy systems. J Dairy Sci., 90: 3671-3680.

Khalil, W. K. B.; M. Z. Nessim and K. A. El Masry (2010). Heat-induced changes in heat shock protein genes expression in crossbred and baladi pregnant cows and their offspring. J. Rad. Res. Appl. Sci., 3 (4B):1287- 1303.

Khan, F.A.; S. Prasad and H. P. Gupta (2013). Effect of heat stress on pregnancy rates of crossbred dairy cattle in Terairegion of Uttarakhand, India. Asian Pac. J. Reprod., 2(4): 277-279.

Lemely, C.O.; K. A. Vonnahme; L. R. Tager; K. M. Krause and M. E. Wilson .(2010): Diet-induced alterations in hepatic progesterone $\left(\mathrm{P}_{4}\right)$ catabolic enzyme activity and $\mathrm{P}_{4}$ clearance rate in lactating dairy cows. J Endocrinol., 205: 233-241.

Maya-Soriano, M. J.; F. López-Gatius; C. AndreuVázquez and M. López-Béjar (2013). Bovine oocytes show a higher tolerance to heat shock in the warm compared with the cold season of the year. Theriogenology, 79:299-305.

Morton, J. M.; W. P. Tranter; D. G. Mayer and N. N. Jonsson (2007). Effect of environmental heat on conception rates in lactating dairy cows: Critical periods of exposure. J. Dairy Sci., 90: 22712278.

Nabenishi, H.; H Ohta; T. Nishimoto; T. Morita; K. Ashizawa and Y. Tsuzuki (2011). Effect of the temperature humidity index on body temperature and conception rate of lactating dairy cows in southwestern Japan. J.Reprod. Dev., 57: 450456.

Nebel, R. L.; S.M. Jobst; M. B. G. Dransfield; S.M. Pandolfi and T. L. Bailey (1997): Use of radio frequency data communication system, HeatWatch, to describe behavioral estrus in dairy cattle. J. Dairy Sci. 80(Suppl. 1.):179(Abstract).

Ono, T.; T. Isobe; Y. Morita; L. T. K. Do; F. Tanihara; M. Taniguchi; M. Takagi, and T. Otoi (2016). Effects of parity and season on pregnancy rates after the transfer of embryos to repeat-breeder Japanese Black beef cattle. Arch. Anim. Breed., 59: 45-49.

Oseni, S.; I. Mistzal; S. Tsuruta and R. Rekaya (2004). Genetic components of days open under heat stress. J. Dairy Sci., 87: 3022-3028.

Pavani, K.; I. Carvalhais; M. Faheem; A. Chaveiro; F. Vieira Reis and F. Moreira da Silva (2015). Reproductive performance of Holstein dairy cows grazing in dry-summer subtropical climatic conditions: Effect of heat stress and heat shock on meiotic competence and in vitro fertilization.J. Anim. Sci., 28 (3): 334-342. 
Peralta, O. A.; R. E. Pearson and R. L. Nebel (2005). Comparison of three estrus detection systems during summer in a large commercial dairy herd. Anim Reprod Sci., 87: 59-72.

Pszczola, M.; I. Aguilar and I. Misztal (2009). Trends for monthly changes in days open in Holsteins. J. Dairy Sci., 92, 4689-4696.

Putney, D. J.; J. R. Malayer; T. S. Gross; W. W. Thatcher; P. J. Hansen and M. Drost (1988). Heat stress-induced alterations in the synthesis and secretion of proteins and prostaglandins by cultured bovine conceptuses and uterine endometrium. Biol. Reprod., 39:717-728.

Rivera, F.A. ; L.G. D. Mendonça; G. L. Jr; J. E. P. Santos; R. V Perez; M. Amstalden; A. CorreaCalderón and R. C. Chebe (2011). Reduced progesterone concentration during growth of the first follicular wave affects embryo quality but has no effect on embryo survival post transfer in lactating dairy cows. Reproduction, 141: 333342.

Roelofs, J.; F. López-Gatius; R. H. F. Hunter; F.J. C. M. Van Eerdenburg and C. Hanzen (2010). When is a cow in estrus? Clinical and practical aspects. Theriogenology, 74: 327-344.

Ron, M.; R. Bar-Anan and G. R. Wiggans (1984). Factors affecting conception rate of Israeli Holstein cattle. J. Dairy Sci., 67:854.

Sartori, R., R. Sartor-Bergfelt; S. A. Mertens; J. N.Guenther; J. J. Parrish and M. C. Wiltbank (2002). Fertilization and early embryonic development in heifers and lactating cows in summer and lactating and dry cows in winter. $\mathbf{J}$ Dairy Sci., 85: 2803-2812.

SAS (2002). User's Guide: Statistics, Version 9.0 Edition. SAS Institute Inc., Cary, NC, USA.

Schuller, L. K.; O. Burfeind and W. Heuwieser (2014). Impact of heat stress on conception rate of dairy cows in the moderate climate considering different temperature humidity index thresholds, periods relative to breeding, and heat load indices. Theriogenology, 81: 1050-1057.
Thatcher, W. W.; I. Flamenbaum, J. Block, and T.R. Bilby (2010). Interrelationships of Heat Stress and Reproduction in Lactating Dairy Cows. High Plains Dairy Conference, Amarillo, Texas, p 45:60.

Thatcher, W.W., and R. J. Collier (1986). Effects of climate on bovine reproduction. Pages 301-309. In: Current Therapy in Theriogenology, 2. D.A. Morrow (Ed). W. B. Saunders, Philadelphia.

Torres-Júnior, J. R.; M. F. Pires; W. F. Sá; M. A. Ferreira; J. H. M. Viana; L. S. A. Camargo; A. A. Ramos; I. M. Folhadella; J. Polisseni; C. Freitas; C. A. A. Clemente; M. F. Sá Filho; F. F. Paula-Lopes and P. S. Baruselli. (2008). Effect of maternal heat-stress on follicular growth and oocyte competence in Bos indicus cattle. Theriogenology, 69:155-166.

Vasconcelos, J. L. M.; D.G. B. Demetrio; R. M. Santos; J. R. Chiari; C. A. Rodrigues and O. G. Sa Filho (2006). Factors potentially affecting fertility of lac-tating dairy cow recipients. Theriogenology, 65: 192-200.

Waldman, A.; O. Reksen; K. Landsverk and E. Ropstad (2001). Progesterone concentrations in milk fat at first insemination - effects on non- return and repeat- breeding. J Anim. Reprod., Sci., 65: 3341.

West, J. W. (2003). Effects of heat-stress on production in dairy cattle. J. Dairy Sci., 86, 2131-2144.

White, F. J.; R. P. Wettemann; M. L. Looper; T. M. Prado, and G. L. Morgan (2002). Seasonal effects on estrous behaviour and time of ovulation in non-lactating beef cows. J. Anim. Sci., 80: 3053-3059.

Wolfenson, D.; I. Flamenbaum and A. Berman (1988). Dry period heat stress relief effects on prepartum progesterone, calf birth weight and milk production. J. Dairy Sci., 71:809-818.

Zahed, S. M.; A. A. El-Gaafarawy and M. B. AboulEla (2001). Reproductive performance of a herd of Egyptian Baladi cattle. J. Agric. Sci. Masoura Univ., 26: 5361- 5370.

\section{تأثير الاجهاد الحرارى على معدل الاخصاب وسلوك الثياع فى الابقار البلاية والخليطة فى الموسم الحار فى صعيد مصر احمد إسماعيل ضمرانى الأنى قسم الإنتاج الحيواني، كلية الزراعة والميلية إنيوارد الطبيعية، جامعة أسوان, مصر}

تم اجر اء هذا العمل لدراسة تأثثر الإجهاد الحراري أثناء الموسم الحار على معدل الإخصاب وسلوك الثبياع في الأبقار البلدية

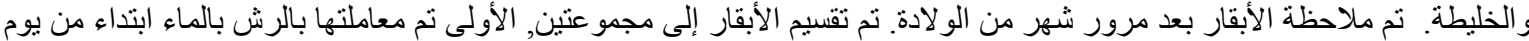

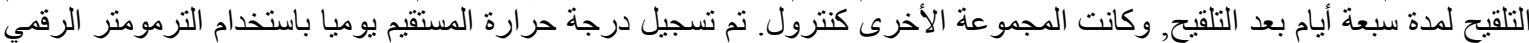

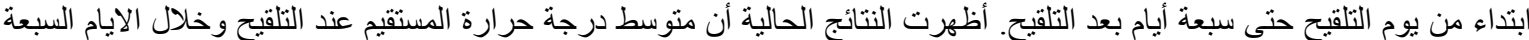

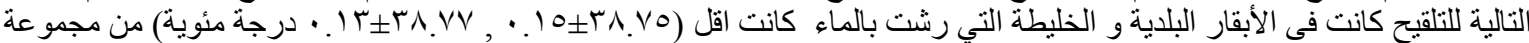

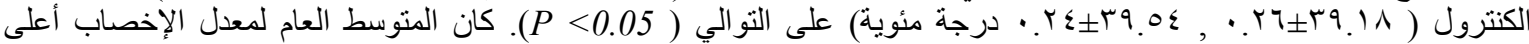

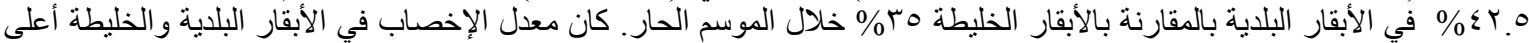

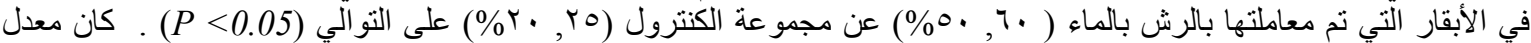

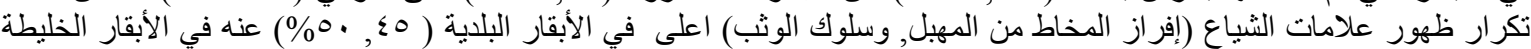

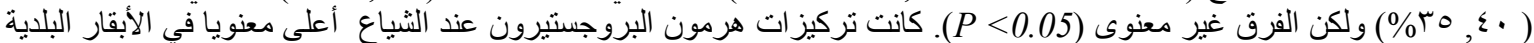

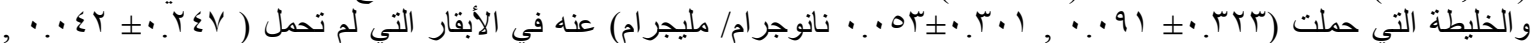

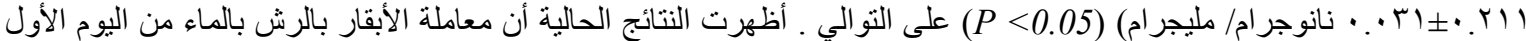

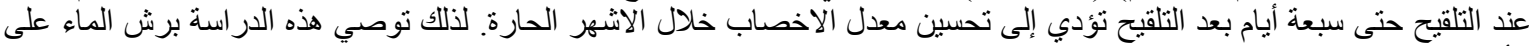
الأبقار قبل وبعد التلقيح مباشرة لتحسين الخصوبة خلاد الموسم الحار تحت الظروف المناخية لمحافظة اسوان. 